\title{
European Monetary Union and Inequality: A Synthetic Control Approach
}

Florentin Kerschbaumer and Andreas Maschke December 2020 


\title{
European Monetary Union and Inequality: A Synthetic Control Approach*
}

\author{
Florentin Kerschbaumer ${ }^{1}$ and Andreas Maschke ${ }^{2}$
}

This version: November 2020

\begin{abstract}
The promise of greater material prosperity and economic convergence has underpinned the process of European economic integration. Its consequences for income inequalities within countries, however, have so far been little discussed. This paper seeks to contribute to the literature by investigating the effects of European economic integration on intra-country income inequality using the synthetic control method. We find that EMU, out of our sample of eight euro countries, has significant effects on inequality in Germany and Spain. From the several theories outlined in the literature, our results lend most support to the growth regime mechanism.
\end{abstract}

\section{Introduction}

The promise of economic convergence and material prosperity has underpinned the process of European economic integration over the past decades. Moreover, the creation of the EMU and the introduction of the euro were justified to no small extent by assurances of substantial welfare gains for participant countries. Headline GDP figures support this narrative. During the first decade of the common currency, EMU periphery countries grew on average faster than their peers from the core. This convergence between countries, however, masked differing convergence processes within countries. While periphery countries broadly observed reductions in income inequality levels during this period, core countries experienced increases. Table 1 summarises this trend, displaying adjusted wage share and after tax Gini figures at the beginning of EMU in 1999 and at the end of its first decade in 2008, coinciding with the Great Financial Crisis and just before the onset of the Eurozone crisis, for selected euro area countries. Even though a secular trend of rising inequality has been well documented for many high-income countries (Piketty, 2014; Milanovic, 2016) and in spite of an extensive literature on the effects of globalisation on inequality (Rodrik, 1997), little research has investigated the consequences of European economic integration for intracountry inequality.

\footnotetext{
* We would like to thank Isabel Martinez and other participants at the 2020 Young Economist Conference of the Austrian Chamber of Labour for helpful comments.

${ }^{1}$ University of Cambridge

2 University of Leeds
} 
Table 1: Adjusted wage shares and after tax Gini for selected euro countries, 1999 and 2008

Adjusted Wage Share

\begin{tabular}{lllllll}
\hline \hline & 1999 & 2008 & $\%$-change & 1999 & 2008 & \%-change \\
Austria & 56.8 & 53.4 & -6.1 & 26 & 27.7 & 6.5 \\
Belgium & 61.5 & 60.8 & -1.2 & 29 & 27.5 & -5.2 \\
Finland & 53.7 & 53.2 & -0.9 & 24 & 26.3 & 9.6 \\
Germany & 58.2 & 55.2 & -5.3 & 25 & 30.2 & 20.8 \\
Netherlands & 59.5 & 56.3 & -5.5 & 26 & 27.6 & 6.2 \\
Core & 58 & 55.8 & -3.8 & 26.0 & 27.9 & 7.2 \\
\hline \hline & & & & & & \\
Greece & 49.5 & 51.8 & 4.6 & 34 & 33.4 & -1.8 \\
Ireland & 49.3 & 52.8 & 7.1 & 32 & 29.9 & -6.6 \\
Portugal & 59.7 & 56.6 & -5.2 & 36 & 35.8 & -0.6 \\
Spain & 59.1 & 57.2 & -3.2 & 33 & 32.4 & -1.8 \\
Periphery & 54.4 & 54.6 & 0.4 & 33.8 & 32.9 & -2.6 \\
\hline \hline Source: Adjusted wage share data taken from AMECO, values as share of GDP. After tax Gini data
\end{tabular}

After Tax Gini taken from Eurostat, values scaled between 0 and 100.

From a theoretical perspective, economic integration, and thus EMU, can be expected to impact income inequality through several mechanisms, not all of which necessarily pull into the same direction. Trade and technology mechanisms, which alter the relative prices of capital and labour, are popular amongst neoclassical economists in explaining the effects of integration on inequality (Acemoglu, 2002; Krugman, 2008). Political economy explanations meanwhile look at institutional factors to explain inequality patterns (Rodrik, 1997; Kohler et al. 2019). We outline a financialisation and a European economic governance mechanism that highlight changes in the power relations between capital and labour as affecting inequality developments. The latter also encompasses a growth regime mechanism which we argue to influence inequality through its variegated effect on wage developments.

This paper contributes to the handful of empirical studies assessing the relationship between closer European economic integration, specifically monetary union, and within country inequality. Contrary to the existing panel econometrics-based literature, we employ the 
synthetic control method, a quasi-experimental technique for counterfactual analysis, to the question at hand. We find EMU to have had pronounced effects on inequality developments in Germany and Spain, increasing inequality in the former, while reducing it in the latter. We see our results in line with the growth regime channel, which has also been identified by Matthijs (2016) as a driver behind the divergent inequality patterns in the euro area. Pursuing an export-led strategy, Germany suppressed wages to boost exports and dampen imports, entailing negative repercussions for its income distribution. Spain, on the other hand, engaged in a debt-fuelled consumption and real estate boom with beneficial consequences for wage growth. We report insignificant results of EMU on inequality for four other euro area member states, for which we were able to construct valid counterfactuals ${ }^{3}$.

The paper is structured as follows: Section 2 discusses the different theoretical channels through which economic integration can impact on inequality and reviews the relevant empirical literature. Section 3 introduces the synthetic control methodology and discusses its advantages and disadvantages over panel econometric approaches. Section 4 outlines the data used in the empirical analysis. Section 5 presents and discusses the estimation results. Section 6 concludes.

\section{Theoretical Motivation and Empirical Findings}

This section outlines the theoretical motivation behind our research question and reviews empirical studies investigating it. We distinguish between two channels through which European economic integration, and in particular EMU, can be argued to affect within-country household inequality: a market channel and a political economy channel. In both channels, several mechanisms are at play that can pull in opposite directions. From a theoretical standpoint, it is thus a priori not clear what the overall effect of European economic integration on inequality should be. We will also review empirical literature concerned with these channels. We start by discussing the market channel.

\section{The market channel}

EMU is the pinnacle of European economic integration. By eliminating exchange rate risks and enhancing market integration, it has deepened trade and financial ties between euro area member states allowing the market channel to unfold (Baldwin et al., 2003). When interested in the effects of economic integration on inequality, the literature typically identifies two

\footnotetext{
${ }^{3}$ These are Finland, France, Ireland and Italy. We failed to produce valid counterfactuals for Greece and Portugal.
} 
mechanisms through which market forces influence the income distribution: the trade and technology mechanisms. For both of these, changes to inequality are seen as the outcome of changes to relative factor prices.

\section{The trade mechanism}

In a Heckscher-Ohlin trade framework, the Stolper-Samuelson theorem (Stolper and Samuelson, 1941) holds that international trade will lead to relative wage increases for skilled workers vis-á-vis unskilled workers in capital abundant countries and to relative wage increases for unskilled workers vis-á-vis skilled workers in labour abundant countries. It thus predicts trade to increase inequality in capital abundant countries, while decreasing it in labour abundant countries (see also Krugman, 2008 for a more contemporary context). Though core assumptions of the theorem such as full employment and capital immobility have been grossly violated for years, the theorem still enjoys popularity in the literature. Mapped onto the EU setting, it can be interpreted as predicting an increase of inequality for EU core countries, while decreasing it for the EU periphery. Arestis and Phelps (2018) report results that lean in that direction, with trade integration lowering inequality for EU periphery countries and no effect on EU core countries. In an analysis covering both developed and developing countries, Stockhammer (2017), however, finds that increased trade integration increases inequality for both country groups. Such a result can be interpreted to be in line with subsequent contributions to neoclassical trade theory that argue that offshoring can lead to an overall increase of inequality, given that the offshored activities are considered high skill in the destination country (Feenstra and Hanson, 1996).

\section{The technology mechanism}

A popular argument advanced by neoclassical theorists to explain rising wage inequality since the 1980s relates to skill biased technological change. The basic tenant of this hypothesis is that recent technological advances - instead of being factor neutral - have favoured skilled labour over unskilled labour, leading to a wage premium for skilled workers which is seen as driving wage inequality (see Acemoglu, 2002 for an overview and Card and DiNardo, 2002 for a critical assessment). As far as trade also leads to a diffusion of technologies across countries, trade integration can be argued to increase inequality in the technology importing country. Thus, by intensifying trade links between member states and therefore increasing the diffusion of technology, EMU can be expected to affect inequality. An IMF study from 2007, using a panel of 18 advanced OECD countries covering the period $1982-2002$ and investigating the determinants of the wage share, reports results supporting this hypothesis (IMF, 2007). The technology channel, measured by the ICT (information and communications 
technology) capital stock, displays larger effects than the globalisation channel, measured through trade prices, offshoring and immigration (ibid.); though the difficulty of disentangling the two channels is admitted by the authors. Using a large panel of 51 countries covering both developing and developed countries, Jaumotte et al. (2013) also find that within country inequality developments - measured by the Gini index - have especially been driven by the technology channel. Globalisation effects, on the other hand, are found to largely offset each other, with globalisation in trade reducing inequality and financial globalisation increasing inequality. The authors argue that the increasing effect of financial globalisation on inequality can also be explained by the skill bias hypothesis, as their results are mostly driven by inward FDI flows into high skill industries. Stockhammer (2017), likewise covering developing and developed countries, on the other hand only finds small effects of technology on inequality and reports results that give primacy to trade and especially financial globalisation measures.

\section{The political economy channel}

Contrary to the market channel, the political economy channel explains inequality developments from an institutional perspective. Changes in the power relations between capital and labour are seen as an important determinant of both personal and functional income distribution. A strengthening of capital's hand over labour is generally seen as increasing inequality. Rodrik (1997) is an early and well-known contribution making this argument. We distinguish between two mechanisms: the financialisation mechanism and the political economy of European economic governance mechanism.

\section{The financialisation mechanism}

The effects of financialisation - a shorthand for capturing the expansion of financial services, the growth of the financial sector and financial profits and the growing importance of financial relations for social relations - on inequality are a central research theme for heterodox economists, especially scholars working from a post Keynesian perspective. In a recent article, Kohler et al. (2019) distil four mechanisms through which financialisation can be seen to potentially impact the wage share (e.g. through the increased financial vulnerability of workers due to higher indebtedness). The unifying theme for these mechanisms is that they conceptualise the impact of financialisation on inequality through a change in power relations between capital and labour in capital's favour. Financialisation is thus expected to negatively impact the income distribution.

In a panel regression analysis covering both developing and developed countries, Stockhammer (2017) provides evidence supporting this theory, reporting strong negative 
effects of financialisation on the (private sector adjusted) wage share as well as negative effects of welfare state liberalisation. The author operationalises financialisation as the logarithm of the sum of external assets and liabilities divided by GDP. This is a de facto measure of financial globalisation compiled by Lane and Miles-Ferretti (2007) and measures a country's exposure to the international financial system. Kohler et al. (2019) also report a negative effect of financialisation on the wage share similar in magnitude to globalisation effects (measured as trade openness). From the four theoretical channels of financialisation identified and operationalised by the authors, financial openness, measured by the Chinn-Ito capital account openness index (Chinn and Ito, 2008), is the most significant.

\section{The political economy of European economic governance mechanism}

The economic governance and policy infrastructure of the EMU can be argued to influence inequality developments within member states. With tight rules for fiscal policy and a central bank governed by a very narrow monetary policy mandate, the EMU economic architecture has from the very outset favoured economic policies with a deflationary stance, exacerbating inequality by limiting the scope for social and redistributive policies. Using a dynamic fixed effects estimation methodology, Agnello et al. (2016), for example, find that fiscal consolidation leads to increased income inequality in their sample of $13 \mathrm{EU}$ countries. In a pooled OLS estimation covering 14 countries, Bertola (2010) suggests that by reducing policy space for national governments and entailing lower social spending, EMU has increased income inequality. Building a similar argument, Bertola (2016) develops a model showing that EMU incentivises liberalising labour market reforms in capital abundant countries, leading to increased inequality.

Non-expansionary fiscal policy was further enshrined in EMU governance in the aftermath of the financial and euro area crisis that led to a tightening of fiscal rules through the Fiscal Compact, the Sixpack legislation and the introduction of the European Semester. These developments have led early observers to compare the crisis management of the EU with the ideas of authoritarian liberalism as developed by the German conservative reactionary Carl Schmitt (Oberndorfer, 2012; Streeck, 2015).

The macroeconomic developments within the EMU have also been analysed from a growth model perspective. The majority of this literature strand comes from post Keynesian scholars (Stockhammer 2016; Stockhammer et. al 2016), but the theoretical concept has recently also been met with interest from the comparative capitalism field (Baccaro and Pontusson, 2016, 2018; Nölke, 2016). In a nutshell, the theory states that EMU's institutional set-up incentivised different economic policy and growth regimes in member states, with each of them relying on 
different components of aggregate demand and none of them guaranteed to be successful, as the case of Italy exemplifies. ${ }^{4}$ Northern Europe, with Germany being the prime example, thus engaged in an export driven, neo-mercantilist growth regime, which relies on successful wage suppression throughout the economy, low inflation and keeping domestic demand in check. Southern Europe, and here especially Spain, on the other hand, relied on a debt-driven consumption and real estate bubble boom for its growth performance. By relying on mass consumption and low skill sectors like the real estate industry, the southern model can be argued to have more favourable outcomes for inequality. The northern model, on the other hand, by necessitating wage moderation both to boost exports and to keep domestic demand in check, could be seen to increase inequality. This is indeed the argument put forward by Matthijs (2016) to explain the divergent and reversing inequality patterns initial euro countries experienced since the inception of the single currency. While the author carefully dissects the institutional machinations at work, he does not include an empirical analysis in his study.

\section{EMU and inequality: some empirics}

Arestis and Phelps (2018), Bertola (2010), Bouvet (2010) and Cesaroni et al. (2019) are empirical studies that explicitly look at the relationship between European economic integration and inequality. Before proceeding with our own analysis, we will briefly review these studies and their findings.

The most recent contribution, Cesaroni et al. (2019), uses an IV GMM estimation technique to investigate the determinants of income inequality in 12 EMU countries spanning the period 1980 to 2015 . The authors use trade and financial openness indicators to proxy the effect of European integration. Their results suggest that the integration process has had different effects for core and periphery countries. Interestingly, in their baseline specification they find that financial openness has decreased inequality for the whole sample over the entire sample period (Table 1, p. 7). This result is driven by Southern periphery countries for which this effect also holds when only the EMU period is considered. These results run counter to the financialisation mechanism outlined above. A problem of their analysis is that it encompasses EMU countries only. This makes it impossible to disentangle the European integration effect from general globalisation effects, as no counterfactual is provided.

Arestis and Phelps (2018) deploy both dynamic and static panel regression techniques to gauge the effects of EMU on within country income inequality. They focus on finance, technology and trade channels in their analysis. They find that the overall effect of EMU has

\footnotetext{
${ }^{4}$ Average GDP growth rate for the euro area was 2.1 per cent during the first ten years of EMU, compared with 1.2 per cent for Italy.
} 
been to decrease inequality, a result driven by the decreasing effect of trade on inequality. While the overall EMU effect is found to decrease inequality, an overall EU effect is found to increase inequality. As the authors note, this probably suggests that their EU dummy variable captures integration effects separate from trade and financial effects, like institutional effects. Like Cesaroni et al. (2019), Arestis and Phelps also break down their sample into different country groups. They too find considerable heterogeneity amongst these. The breakdown into country groups reveals that the overall EMU effect disappears for core countries, while it continues to decrease inequality for non-core countries. The results are driven by the trade effect, which is found to reduce inequality in non-core countries while remaining insignificant for core countries, thus supporting the predictions of the Stolper-Samuelson theorem. The technology channel remains insignificant, while the financial channel is reported to reduce inequality in core countries while increasing it in non-core countries.

As noted above, the results in Bertola (2010) suggest EMU has increased income inequality in member states. This is in contrast to the results reported in Arestis and Phelps (2018). Unlike the latter, Bertola (2010) does not split his sample into different country groups. Thus, his overall results might mask country group heterogeneity reported in both Arestis and Phelps (2018) and Cesaroni et al. (2019). An additional caveat is that by using a pooled OLS, Bertola (2010) risks leaving unobservable factors unaccounted for. The short sample, covering the years 1995 - 2005, also means that important dynamic and longer-term effects of EMU are not captured by the estimation.

Bouvet (2010) dissects the inequality implications of EMU on a regional instead of country level for the period 1977 - 2003. She employs a panel fixed effects methodology and finds that EMU has worsened regional disparities in poorer countries while reporting insignificant effects for richer countries. Bouvet uses a dummy variable to measure the EMU effect and does not consider the channels outlined above individually. By also relying on a static model like Bertola (2010) and only including five EMU years in her sample, longer-term dynamics of EMU on inequality are not captured.

As this section has highlighted, the overall impact of European economic integration on within country income inequality is a priori unclear from a theoretical perspective. The different channels and mechanisms identified predict at times opposing tendencies. On the one hand, the financialisation literature, the technology mechanism and the political economy channel imply on average negative effects of closer economic integration for within-country inequality. The implications of the trade mechanism for the income distribution, on the other hand, depend on the country in question and its respective factor endowments. The empirical literature surveyed above also paints an inconclusive picture of the consequences of economic 
integration for inequality. Studies such as Stockhammer (2017) and Kohler et al. (2019) report financial globalisation as increasing inequality, while Cesaroni et al. (2019) report it as decreasing it for EMU members and Arestis and Phelps (2018) report opposing effects for EMU core and periphery countries. IMF (2007) and Jaumotte et al. (2013) both find the technology channel to be an important driver of inequality while Stockhammer (2017) only finds small evidence for this channel and Arestis and Phelps (2018) report it as insignificant. Similarly, Stockhammer (2017) and IMF (2007) find trade globalisation as increasing inequality. Meanwhile, Jaumotte et al. (2013) find it to decrease it and Arestis and Phelps (2018) report it to decrease inequality in EMU periphery countries while not affecting EMU core countries.

\section{Methodology}

To perform our analysis, we use the synthetic control method for comparative case studies, pioneered by Abadie and Gardeazabal (2003) and extended by Abadie et al. (2010, 2011, 2015). The method compares the dependent variable of interest, country-level income inequality, in the country of interest to an artificially constructed counterfactual. This 'synthetic' control unit is constructed using a convex combination of control countries (the 'donor pool') that best resembles the treatment unit before the intervention takes place, using data on both the outcome variable as well as a set of covariates that correlate with the outcome variable. The trajectories of the outcome variable for the treatment country and the synthetic control can then be compared to assess the effect of the treatment.

The method has previously been used to analyse EMU's effect on GDP per capita (Férnandez and Perea, 2015) and real exchange rates (El-Shagi et al., 2016), the impact of the Stability and Growth Pact on member states' government debt (Köhler and König, 2015), the economic benefits of the EU (Campos et al., 2014), as well as the effect of EMU on current account balances prior to the Great Financial Crisis (GFC) (Hope, 2016).

Formally, the method works as follows: Assume a sample of $k+1$ countries. The first country, $k=1$, is the country for which the synthetic counterfactual should be constructed. All the other countries in the sample are the countries which are used to construct the synthetic control. These countries are referred to as the donor pool. The time period under consideration, $T$, runs from 1975 to 2006. $T$ is split into two subsamples, a pre-intervention period $T 0$ and a post-intervention period $T 1$. In our case, $T 0$ is the period prior to the start of EMU, i.e. 1975 to1998. $T 1$ covers the period from 1999 to 2006 , the year before the onset of the GFC. 
The aim of the method is to use $T 0$, the "training period", in order to create the synthetic control unit which best resembles the characteristics of the country $k=1$. The country characteristics include the dependent variable as well as a set of covariates which are correlated with the dependent variable. As all countries in the donor pool are different from the country of interest, the method creates a weighted average of the donor pool's characteristics which resembles $k=1$ most closely. Therefore, the method chooses weights $W=\left(w_{2}, \ldots, w_{k+1}\right)$ for each country from the donor pool. The weights are chosen to be between zero and one and the sum of all weights equals one, thus $0 \leq w_{k} \leq 1$ with $k=2, \ldots, k+1$ and $\sum_{k} w_{k}=1$. The synthetic control unit is thus a convex combination of the countries in the donor pool with the factors given by $W$. In choosing the factor weights $W$ we follow Abadie et al. (2015) so as to minimize the mean squared prediction error (MSPE) between the characteristics for the treatment country and the synthetic control unit. Furthermore, we follow Abadie et al. (2010) in choosing the relative weights of the dependent variable and each of the covariates so as to also minimize the MSPE $^{5}$.

The advantage of the synthetic control method over traditional panel regression techniques is that the latter "require large samples and many observed instances of the event or intervention of interest and, as a result, they are often ill-suited to estimate the effects of infrequent events, such as policy interventions, on aggregate units" (Abadie 2020, p. 4). On the other hand, the synthetic control unit combines the advantages of comparative case studies, which are wellsuited for estimating the effect of one-time interventions, with a rigorous, data-driven approach to selecting/constructing the counterfactual. This creates a quasi-experimental setting, allowing for a more rigorous estimation of causal effects compared to panel regressions which are better suited for observing correlations. Thus, while the synthetic control method does not allow for the disaggregation of overall effects into different channels as outlined in Section 2, it results in a more robust estimate of the overall effect of EMU on inequality as compared to a panel regression.

As the synthetic control method does not lend itself to classic methods of statistical inference we employ so-called in-space placebos to assess the validity of the findings (Abadie, 2020). The procedure randomly reassigns the treatment to units from the donor pool and compares them with their optimal synthetic control unit (constructed using the other donor pool units). Similarly large results of the synthetic control estimation for the placebo treatments would indicate that the observed effects for the real treatment unit are not due to the treatment effect.

\footnotetext{
${ }^{5}$ We omit a detailed formal description of the process for choosing weights which can be found in Abadie et al. (2020).
} 
This allows for the construction of $p$-values, as exposing all donor units to the treatment will generate a distribution of intervention effects against which the true synthetic control estimate can be compared.

\section{Data}

To conduct the estimation we use a yearly panel dataset running from 1975-2006 ${ }^{6}$. The main outcome variable is market household income inequality, as measured by the before-tax Gini coefficient. The outcome variable data stems from the Standardized World Income Inequality Database (Solt, 2020). Our covariates to estimate the synthetic control units include the dependent variable - market income inequality - as well as a number of covariates. The choice of covariates is informed by Hartwell et al. (2019) and Carey and Horiuchi (2013). We use real GDP per capita, the country's overall population as well as population density, the employment rate (of the working age population), trade openness, the share of adults who have completed (i) secondary and (ii) tertiary education, the degree of financial market openness, the capital stock as a share of GDP, the government consumption share of GDP and the share of labour compensation over GDP. We expect all these variables to be correlated with income inequality across countries. The data on covariates comes from the Penn World Tables (GDP, employment rate, trade openness, government share, labour share $)^{7}$, the Barro-Lee education database (secondary and tertiary education) ${ }^{8}$, the United Nations World Population Prospects (population and population density) $^{9}$, and the Chinn-Ito database (financial market openness) ${ }^{10}$.

To deal with missing observations for covariates we linearly interpolate missing values if we have observations for both the year preceding and the year following the missing value. Observations with missing values at either the beginning or the end of the dataset are dropped. As a result, we obtain a balanced panel dataset with 34 countries, containing 8 potential treatment countries and 26 potential controls. While the synthetic control literature often restricts the donor pool to countries that are geographically close to the treatment country, we opt for an unrestricted control pool of OECD countries. The high number of treatment cases combined with a control country restriction based on geographical proximity would limit the

\footnotetext{
${ }^{6}$ We end our estimation period with 2006 as this represents eight years after the introduction of EMU and should thus capture most of the effects of EMU on inequality. Extending the sample beyond that would increase the likelihood of other policy changes or economic events affecting inequality and thus diluting the effect of EMU.

${ }^{7}$ https://cran.r-project.org/web/packages/pwt9/pwt9.pdf

8 http://www.barrolee.com/

9 https://population.un.org/wpp/Download/Standard/Population/

10 http://web.pdx.edu/ ito/Chinn-Ito website.htm
} 
dataset to only four potential control countries (Hungary, Norway, Sweden, and the UK). However, to avoid the synthetic control units being constructed from countries too dissimilar to the treatment cases, we limit our dataset to OECD countries only, resulting in a dataset of 10 control countries ${ }^{11}$. As an additional robustness check we rerun the estimations using an expanded control sample of upper-middle income and high-income countries.

\section{Results}

Given data availability constraints, we conduct estimations of the effect of EMU on inequality for Finland, France, Germany, Greece, Italy, Ireland, Portugal, and Spain. Although this is only a subset of EMU countries, it presents a wide range of different types of political economies in Europe with different levels of income and economic development, and different regimes governing capital and labour markets, taxation, welfare states (Esping-Andersen, 1990).

One of the crucial assumptions for the synthetic control method to work is that the pretreatment trajectory of the synthetic unit closely resembles the trajectory of the actual unit (Abadie, 2015). Only then can a divergence of post-treatment trajectories be truly interpreted as representing the results of the treatment. The pre-treatment mean squared prediction error can be used as a metric to quantify the difference between the treatment unit and its synthetic control. A too large MSPE suggests that the synthetic control unit does not track the pretreatment unit closely and invalidates the results. We follow Abadie (ibid.) in using 2 as a threshold for the MSPE. Table 2 summarizes the MSPE for each of the treatment countries. The synthetic control method is able to sufficiently track the pre-treatment trajectories of all treatment countries except for Greece (3.28) and Portugal (MSPE 3.66). To err on the side of caution we exclude both Greece and Portugal from the results discussion.

\footnotetext{
${ }^{11}$ The list of control countries is: Australia, Canada, Chile, Hungary, I Japan, Mexico, Norway,
} Sweden, United Kingdom, United States; 
Table 2: Pre-treatment MSPE for treatment countries

\begin{tabular}{|l|l|l|}
\hline Country & MSPE & MSPE below 2 \\
\hline Finland & 0.31 & TRUE \\
\hline France & 1.29 & TRUE \\
\hline Germany & 0.23 & TRUE \\
\hline Greece & 2.67 & FALSE \\
\hline Ireland & 0.24 & TRUE \\
\hline Italy & 0.73 & TRUE \\
\hline Portugal & 3.66 & FALSE \\
\hline Spain & 0.31 & TRUE \\
\hline
\end{tabular}

Note: The MSPE was calculated over the pre-treatment period of 1975 to 1998.

Table A1 in the Appendix gives the weight of the control countries making up each of the synthetic units for the treatment countries. In addition, Table A2 gives the relative importance of each of the covariates used to estimate the synthetic control units (including only countries with nonzero weights).

The results of the comparison between the treated units and their synthetic controls are presented in Figure 1 and Figure 2. Figure 1 shows the trajectories of the treated unit (dashed line) and its synthetic control (solid line) for the entirety of our dataset. The blue vertical line represents the onset of the treatment, the start of EMU. EMU can be said to have an effect on inequality if the trajectory of the treatment and synthetic control lines diverge considerably after the onset of EMU. Figure 2 zooms in on the gaps between treated units and their synthetic controls. 
Figure 1: Path plots for treatment units

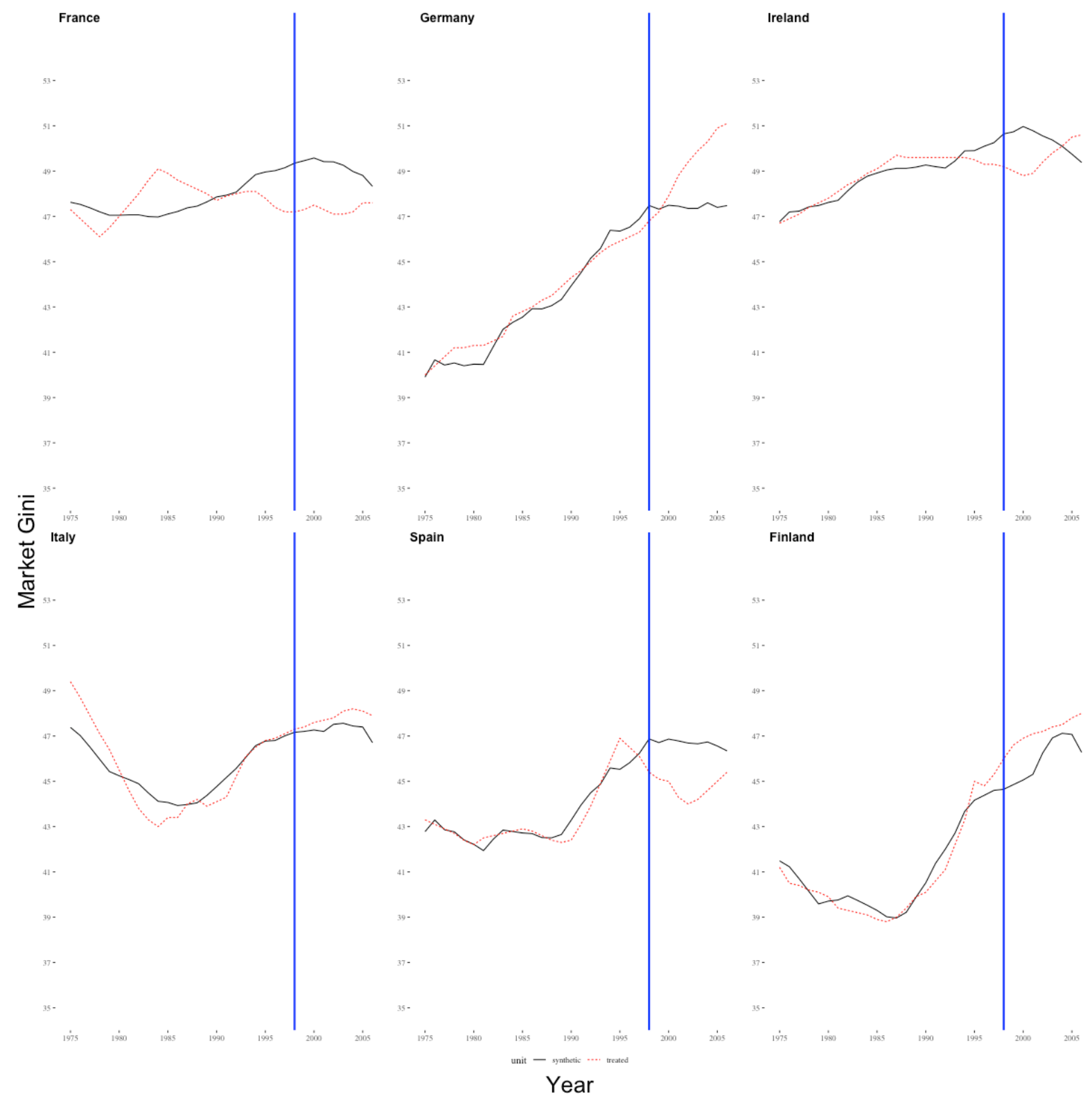


Figure 2: Gap plots for treatment units

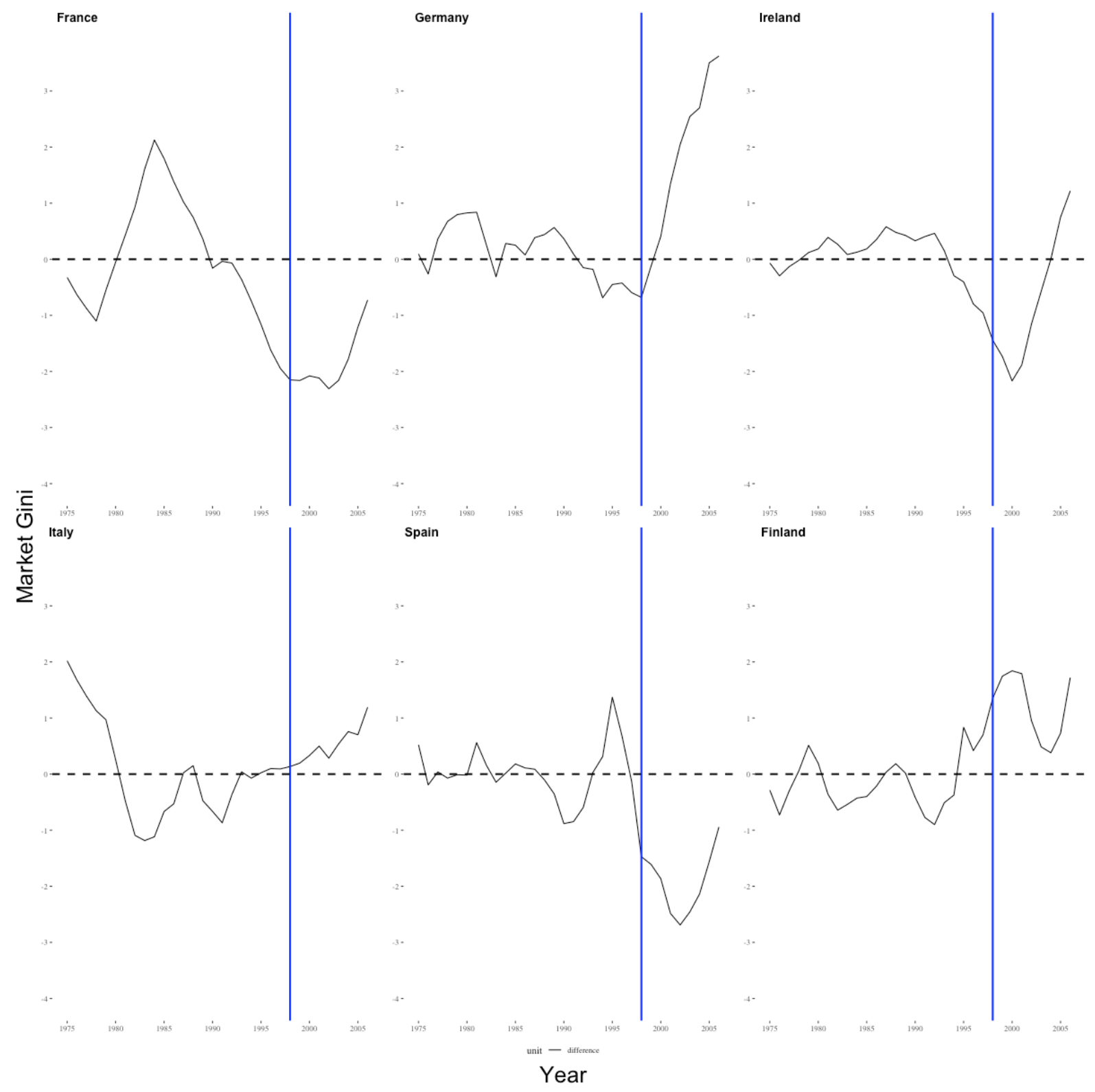

To be able to gauge the significance of the effect of EMU treatment on inequality in our sample we rely on the use of placebo tests (Abadie 2020) for each of our treatment units. As discussed in the methodology section, in-space placebos artificially reassign the treatment (EMU) to each of the control countries in the donor pool. Subsequently, we estimate an additional synthetic control unit for each of the control countries. Each control unit and its new synthetic control is then compared by computing the post/pre-MSPE ratio, i.e. the ratio of the effect size after treatment (the MSPE from 1999-2006) to the goodness of the fit of the synthetic control before treatment (the MSPE as per Table 2). This procedure ensures that the post-treatment effect is weighted by the goodness of fit of the synthetic control and reduces the effect of random deviations. We therefore obtain a distribution of effect sizes for an artificial treatment. Only if 
the effect size for the actually treated unit (e.g. France) is sufficiently larger than the average of the effect sizes for each of the artificially treated control countries can we reject the null hypothesis of no effect of EMU introduction on inequality. Figures A1-A8 in the Appendix show the distribution of results of the placebo tests. In-space placebos also allow for the calculation of p-values (Abadie 2020) which simply represent the relative rank of the post/pre-MSPE of the treated country versus all other countries in the donor pool. Table 3 provides the results of these placebo tests.

Table 3: $p$-values of placebo tests for treatment countries

\begin{tabular}{|l|l|l|}
\hline Country & p-value & Relative ranking in placebo distribution \\
\hline Finland & 0.27 & $3 / 11$ \\
\hline France & 0.54 & $6 / 11$ \\
\hline Germany & $0.09^{*}$ & $1 / 11$ \\
\hline Ireland & 0.18 & $2 / 11$ \\
\hline Italy & 0.81 & $9 / 11$ \\
\hline Spain & $0.09^{*}$ & $1 / 11$ \\
\hline
\end{tabular}

Note: * denotes the test being significant at the $10 \%$ level. Note that due to the discrete nature of the testing procedure (comparing ranks), the minimum p-value that can be achieved is 0.09 as the sample size of the donor pool is 11 .

\section{Discussion of cases}

For Finland, France, Ireland, and Italy there is no clear significant effect of EMU on inequality. (i) The synthetic control unit of France is below pre-EMU inequality of real France in the 1980s and moves above it in the mid-1990s, about 5 years before EMU introduction. The gap between synthetic and real units therefore already exists at the time of treatment and cannot be attributed to EMU introduction. Concurrently, France's p-value from the placebo test is at 0.54 , making rejection of the null hypothesis of no EMU on inequality effect unlikely. (ii) In the case of Ireland, the synthetic unit tracks real Ireland well but also overshoots inequality of the real unit in the years before EMU introduction. The gap between the synthetic and real unit narrows after EMU introduction and disappears by about 2004. Although Ireland has a lower p-value (0.18), the magnitude of the effect is too small to be of significance. (iii) For Italy, the synthetic unit is able to track the U-shaped curve of inequality in real Italy in the 1980s and 1990s with only a slight divergence of the two units in the 1980s. EMU introduction shows a slight effect with inequality in real Italy exceeding its synthetic counterpart. However, a very 
high p-value (0.81) makes attribution of a significant EMU effect impossible. (iv) The case of Finland looks promising. Not only does the synthetic unit track real Finland well before EMU but there is also a noticeable divergence between the two after the onset of EMU. However, the gap starts to emerge about two years prior to the introduction of EMU and the overall effect also does not seem particularly pronounced. This conclusion is bolstered by a p-value 0.27.

The strongest results are visible for the case of Germany. The tracking of the synthetic unit is exceptional (MSPE of 0.03 ) and the start of EMU coincides with a very clear divergence of the real and synthetic units. From 1999 onwards inequality of real Germany soars by about 4 Gini percentage points compared to its synthetic counterpart. This is a clear indication of the effect that EMU has on inequality in Germany. While many idiosyncratic policy changes occurred in Germany during the 1990s and 2000s none of them coincide that clearly with the divergence in inequality between synthetic and real units as the onset of EMU : German reunification, which could arguably effect income inequality simply due to the fact that Eastern Germany was significantly poorer than Western Germany at the time of reunification, went into effect in 1990 already. The ability of synthetic Germany to track real German inequality up until 1999 negates any effect of German reunification on these results. In a similar vein, the far-reaching social policy reforms in Germany ("Agenda 2010") only started in late 2003 and did not come into full effect until 2005. The divergence between synthetic and real Germany clearly precedes this. The significance of these effects is corroborated by a p-value of $0.09 .{ }^{12}$

We also observe significant results for the case of Spain. While the tracking of the synthetic unit is somewhat less accurate than in the case of Germany, synthetic Spain still tracks real Spain quite well (MSPE of 0.42) with slight divergences in inequality around 1990 and 1995. The two units converge just before the treatment period, however. Following the start of EMU, we see a clear trend of decreasing inequality in Spain compared to its synthetic unit, culminating in a difference of about 3.5 percentage points between real and synthetic Spain by 2004 . There is no policy event of a significance similar to EMU introduction happening in Spain at the end of the 1990s that could explain this effect. Similar to Germany, the p-value for Spain stands at $0.09^{13}$.

Overall, our results lend most credibility to the growth-model perspective (Stockhammer 2016; Matthijs, 2016; Baccaro and Pontusson 2018), which sees growth caused by different

\footnotetext{
${ }^{12}$ Given the size of the control sample ( $\left.n=11\right)$, a $p$-value 0.09 is the lowest $p$-value that can be achieved and corresponds to the pre/post-MSPE ratio in Germany being higher compared to all placebo counterparts.

${ }^{13}$ Again coinciding with the highest ranking in the pre/post-MSPE ratio.
} 
components of effective demand in different economies. Specifically, it can be argued within this theory that EMU will lead to an increase in inequality in export-oriented political economies as these restrain wages to achieve a competitive real exchange rate, muted domestic demand and, consequently, a positive trade balance. These developments foster higher inequality as a dualized economy between a highly competitive and high-paying sector for tradables and a wage-suppressed non-tradable sector emerges. On the other hand, the prediction is for debtoriented political economies to achieve lower levels of inequality under EMU as the fixing of the nominal exchange rate and access to European financial markets allow for greater levels of real fiscal expansion and overleveraging. These will in turn lead to high levels of domestic demand, creating jobs and raising wages for the low-skilled in sectors such as construction and therefore lowering inequality.

The growth model perspective also helps to explain why we fail to find an effect of EMU on inequality for Finland, France, Ireland and Italy - that is why we cannot reject our $\mathrm{H}_{0}$ for these countries.

In the case of Finland, we do observe a slight exacerbating effect of EMU introduction on income inequality. This result is in line with expectations as Finland is usually classified as an export-driven economy (Nölke, 2016). However, the size of the effect is significantly smaller than in the case of Germany. Two factors explain this divergence: First, while maintaining a current account surplus throughout, Finland simultaneously had high wage growth throughout the 1990s and the 2000s, making its growth model less dependent on exports and more reliant on domestic consumption. This in turn weakens the effect that EMU introduction had on exacerbating inequality. Second, Finland suffered a severe financial crisis in the early 1990s. The strong rebound effect observed during the late 1990s coincides with EMU introduction, thus blurring its potential effect of increasing inequality.

We observe similarly ambiguous results for France. This comes as no surprise as the literature on comparative capitalism classifies France as fitting neither fully into the export-led nor the demand-led growth model. In particular, France is characterized by both a large domestic nontraded sector as well moderate wage settlements engineered by the state (Johnston and Regan 2016).

Just as with Finland, the results for Ireland point in the right direction. The Post Keynesian literature normally classifies Ireland as a debt-led country (Stockhammer, 2016; Stockhammer et al., 2016; Kohler and Stockhammer, 2020), with the comparative capitalism literature seeing it as more of a borderline case (Johnston and Regan, 2016; Nölke, 2016). We would thus 
expect inequality in synthetic Ireland to overshoot real Ireland, which is indeed what we observe. A major problem for our estimation, however, is that the Good Friday Agreement, which ended decades of violence and terror across the island of Ireland, was signed in 1998, just a year prior to the start of EMU. Such major events coinciding with each other makes it very difficult to credibly disentangle their effects on our outcome variable. We still report our results for Ireland for the sake of completeness but would advise for caution in their interpretation.

Finally, it is also not surprising that we fail to find a substantial effect of EMU on inequality developments in Italy. Italy's GDP growth performance has been poor since the start of EMU, averaging a meagre 1.2 per cent during the first decade of the euro, compared with 2.1 per cent for the euro area. Italy failed to adopt a successful growth strategy under the euro and hence we also find no effect of EMU on inequality developments there.

While we do not find a significant impact of EMU on inequality for Finland, France, Ireland, and Italy we do observe fairly large (between 3 and 4 percentage points) effects on inequality in the two archetypical cases for each growth model, Germany and Spain. As expected, EMU leads to higher inequality in the export-oriented growth model of Germany whereas it lowers inequality in the debt-oriented growth model of Spain.

\section{Robustness checks}

As a robustness check, we re-estimate our results using a donor pool consisting of uppermiddle income and high-income countries ${ }^{14}$. This results in an extended donor pool of 34 countries $^{15}$. We use the same covariates and time periods to estimate these results. The results broadly correspond to that of the baseline model with a restricted donor pool. Figure A9 in the Appendix gives detailed results. For all countries we observe a similar sign and size of the effect for the restricted control pool, increasing confidence in our results. In particular, the gap in post-treatment inequality between the synthetic and real unit increases to about (negative) 2.5 percentage points until 2006 for Spain and to about (positive) 3.5 percentage points until 2006 for Germany.

\footnotetext{
${ }^{14}$ We follow the World Bank definition of upper-middle income countries as those with a GNI per capita (PPP) higher than $\$ 3,956$ in 2018 (see https://www.worldbank.org/en/country/mic/overview\#: :text=The\%20world's\%20Middle\%20Income\%2 0Countries,\%243\%2C956\%20and\%20\%2412\%2C235\%20(2018)).

15 The list of control countries is: Argentina, Australia, Brazil, Canada, Chile, Colombia, Costa Rica, Hungary, India, Indonesia, Japan, Malaysia, Mexico, Norway, Panama, Peru, Philippines, Singapore, South Africa, Sri Lanka, Sweden, Thailand, United Kingdom, United States;
} 


\section{Conclusion}

The general economic effects of European Monetary Union have been widely assessed in the literature. However, its effects on inequality have received comparatively little attention. While there have been some studies analysing, both theoretically and empirically, EMU's repercussions for inequality, they provide contrasting empirical findings that lend support to different hypotheses (Bertola, 2010; Bouvet, 2010; Arestis and Phelps, 2018; Cesaroni et al. 2019). The literature suggests multiple channels through which EMU can either lead to an increase or a decrease in inequality. The existing empirical analyses have mostly employed panel regression methods which suffer from low numbers of observations and make it difficult to establish cause and effect. This paper sought to move beyond that restriction by employing a quasi-experimental design, the synthetic control method, to assess the effect EMU has had on inequality within member states.

Using a balanced panel dataset with 34 countries over the 1975-2006 time period and analysing eight different EMU member countries, we find mixed effects of EMU on inequality. On the one hand, for most countries we considered we did not find a significant effect of EMU onset on income inequality. On the other hand, for the two countries with significant results, Germany and Spain, EMU has led to sizable but diverging effects on inequality: Inequality has increased in Germany whereas it decreased in Spain as a result of the introduction of the euro. These results are in line with the predictions of a growth model analysis of European political economies. In this reading, EMU has suppressed wage growth in export-oriented Germany and increased wages for the low-skilled in demand and debt-oriented Spain. Thus, our findings challenge the notion of uniform effects of EMU across different member states and corroborate a dichotomous analysis of European economies where EMU's effects differ depending on the type of political economy and growth regime.

\section{References}

Abadie, A. (2020). Using Synthetic Controls: Feasibility, Data Requirements, and Methodological Aspects. Journal of Economic Literature, Forthcoming.

Abadie, A., \& Gardeazabal, J. (2003). The Economic Cost of Conflict: A Case Study of the Basque Country. The American Economic Review, 93, 113-132.

Abadie, A., Diamond, A., \& Hainmueller, J. (2010). Synthetic Control Methods for Comparative Case Studies: Estimating the Effect of California's Tobacco Control Program. Journal of the American Statistical Association, 105, 493-505. 
Abadie, A., Diamond, A., \& Hainmueller, J. (2011). Synth: An R Package for Synthetic Control Methods in Comparative Case Studies. Journal of Statistical Software, Articles, 42, 1-17. doi:10.18637/jss.v042.i13

Abadie, A., Diamond, A., \& Hainmueller, J. (2015). Comparative Politics and the Synthetic Control Method. American Journal of Political Science, 59, 495-510.

Acemoglu, D. (2002). Directed Technical Change. The Review of economic studies, 69, 781-809.

Agnello, L., Fazio, G., \& Sousa, R. M. (2016). National fiscal consolidations and regional inequality in Europe. Cambridge Journal of Regions, Economy and Society, 9, 59-80. doi:10.1093/cjres/rsv033

Arestis, P., \& Phelps, P. (2018). Inequality Implications of European economic and monetary union membership: A reassessment. Environment and Planning A, 50, 14431472.

Baccaro, L., \& Pontusson, J. (2016). Rethinking Comparative Political Economy: The Growth Model Perspective. Politics \& Society, 44, 175-207. doi:10.1177/0032329216638053

Baccaro, L., \& Pontusson, J. (2018). Comparative political economy and varieties of macroeconomics. MPIfG Discussion Paper, Max Planck Institute for the Study of Societies.

Baldwin, R., Bertola, G., \& Seabright, P. (2003). EMU: Assessing the Impact of the Euro. Blackwell, Oxford.

Bertola, G. (2010). Inequality, integration, and policy: issues and evidence from EMU. The Journal of Economic Inequality, 8, 345-365.

Bertola, G. (2016). Labor policies and capital mobility in theory and in EMU. European Economic Review, 87, 62-77.

Bouvet, F. (2010). EMU and the dynamics of regional per capita income inequality in Europe. The Journal of Economic Inequality, 8, 323-344.

Card, D., \& DiNardo, J. E. (2 2002). Skill Biased Technological Change and Rising Wage Inequality: Some Problems and Puzzles. Working Paper, National Bureau of Economic Research. doi:10.3386/w8769 
Carey, J. M., \& Horiuchi, Y. (2017). Compulsory Voting and Income Inequality: Evidence for Lijphart's Proposition from Venezuela. Latin American Politics and Society, 59, 122-144. doi:10.1111/laps.12021

Cesaroni, T., D'Elia, E., \& Santis, R. D. (2019). Inequality in EMU: is there a core periphery dualism? The Journal of Economic Asymmetries, 20, e00121.

Chinn, M. D., \& Ito, H. (2008). A New Measure of Financial Openness. Journal of comparative policy analysis, 10, 309-322.

IMF (2007). CHAPTER 5 THE GLOBALIZATION OF LABOR. In World Economic Outlook, April 2007 : Spillovers and Cycles in the Global Economy. USA: INTERNATIONAL MONETARY FUND.

Esping-Andersen, G. (1990). Three Worlds of Welfare Capitalism. Princeton University Press.

Feenstra, R. C., \& Hanson, G. H. (1996). Globalization, Outsourcing, and Wage Inequality. The American economic review, 86, 240-245.

Hartwell, C., Horvath, R., Horváthová, E., \& Popova, O. (2019). Natural Resources and Income Inequality in Developed Countries: Synthetic Control Method Evidence. Working Papers, Leibniz Institut für Ost- und Südosteuropaforschung (Institute for East and Southeast European Studies).

Höpner, M. (1 2008). Usurpation statt Delegation: Wie der EuGH die Binnenmarktintegration radikalisiert und warum er politischer Kontrolle bedarf. MPIfG Discussion Paper 08/12 Max-Planck-Institut für Gesellschaftsforschung Köln.

Höpner, M. (2017). Grundfreiheiten als Liberalisierungsgebote? Reformoptionen im Kontext der EU-Reformdebatte. Cologne: Max Planck Institute for the Study of Societies.

Höpner, M., \& Schäfer, A. (Eds.). (2008). Die Politische Ökonomie der europäischen Integration. Frankfurt/Main, New York; Frankfurt a. M.: Campus Verlag.

Jaumotte, F., Lall, S., \& Papageorgiou, C. (2013). Rising Income Inequality: Technology, or Trade and Financial Globalization\&quest. IMF Economic Review, 61, 271-309. 
Johnston, A. \& Regan, A. (2016). European Monetary Integration and the Incompatibility of National Varieties of Capitalism. Journal of Common Market Studies, 54, 318-336.

Kohler, K., Guschanski, A., \& Stockhammer, E. (7 2019). The impact of financialisation on the wage share: a theoretical clarification and empirical test. Cambridge Journal of Economics, 43, 937-974. doi:10.1093/cje/bez021

Krugman, P. (2008). Trade and Wages, Reconsidered. Brookings Papers on Economic Activity, 39, 103-154.

Lane, P. R., \& Milesi-Ferretti, G. M. (2007). The external wealth of nations mark II: Revised and extended estimates of foreign assets and liabilities, 1970-2004. Journal of international economics, 73, 223-250.

Matthijs, M. (2016). The Euro's “Winner-Take-All” Political Economy. Politics \& Society, 44, 393-422.

Milanovic, B. (2016). Global Inequality: A New Approach for the Age of Globalization. Belknap Press.

Nölke, A. (2016). Economic causes of the Eurozone crisis: the analytical contribution of Comparative Capitalism. Socio-Economic Review, 14, 141-161.

Oberndorfer, L. (2012). Die Renaissance des autoritären Liberalismus? Carl Schmitt und der deutsche Neoliberalismus vor dem Hintergrund des Eintritts der "Massen" in die europäische Politik. PROKLA. Zeitschrift für kritische Sozialwissenschaft, 42, 413431.

Piketty, T. (2014). Capital in the Twenty-First Century. Harvard UP.

Rodrik, D. (1997). Has Globalization Gone Too Far? Peterson Institute for International Economics.

Scharpf, F. (2008). Die Politische Ökonomie der europäischen Integration. In M. Höpner, \& A. Schäfer (Eds.). Frankfurt/Main, New York; Frankfurt a. M.: Campus Verlag.

Scharpf, F. (2008a). Die Politische Ökonomie der europäischen Integration. Nachwort. In M. Höpner, \& A. Schäfer (Eds.). Frankfurt/Main, New York; Frankfurt a. M.: Campus Verlag. 
Seikel, D. (2013). Wie die Europäische Kommission supranationales Recht durchsetzt - Der Konflikt um die Liberalisierung des öffentlich-rechtlichen Bankenwesens in Deutschland. Politische Vierteljahresschrift, 54, 292-316.

Solt, F. (2020). Measuring Income Inequality Across Countries and Over Time: The Standardized World Income Inequality Database. Social Science Quarterly, 101, 11831199. doi:10.1111/ssqu. 12795

Stockhammer, E. (2016). Neoliberal growth models, monetary union and the Euro crisis. A post-Keynesian perspective. New Political Economy, 21, 365-379. doi:10.1080/13563467.2016.1115826

Stockhammer, E. (2017). Determinants of the Wage Share: A Panel Analysis of Advanced and Developing Economies. British journal of industrial relations, 55, 3-33.

Stockhammer, E., Durand, C., \& List, L. (2016). European growth models and working class restructuring: An International post-Keynesian Political Economy perspective. Environment and Planning A, 48, 1804-1828.

Stolper, W., \& Samuelson, P. (1941). Protection and Real Wages. The Review of Economic Studies, 9, 58-73.

Streeck, W. (2015). Heller, Schmitt and the Euro. European Law Journal, 21, 361-370. doi:10.1111/eulj.12134 


\section{Appendix}

Table A1: Country weights for synthetic control

\begin{tabular}{|c|c|}
\hline Finland: Synthetic unit countries & Coefficients \\
\hline Canada & 0.05 \\
\hline Hungary & 0.32 \\
\hline Norway & 0.63 \\
\hline France: Synthetic unit countries & Coefficients \\
\hline Chile & 0.43 \\
\hline Japan & 0.08 \\
\hline Mexico & 0.32 \\
\hline Norway & 0.13 \\
\hline United Kingdom & 0.03 \\
\hline Germany: Synthetic unit countries & Coefficients \\
\hline Canada & 0.62 \\
\hline Sweden & 0.16 \\
\hline United Kingdom & 0.22 \\
\hline Greece : Synthetic unit countries & Coefficients \\
\hline Australia & 0.11 \\
\hline Chile & 0.54 \\
\hline Mexico & 0.26 \\
\hline Norway & 0.09 \\
\hline Ireland: Synthetic unit countries & Coefficients \\
\hline Australia & 0.06 \\
\hline Canada & 0.24 \\
\hline Chile & 0.68 \\
\hline United Kingdom & 0.01 \\
\hline Italy: Synthetic unit countries & Coefficients \\
\hline Chile & 0.11 \\
\hline Hungary & 0.02 \\
\hline Mexico & 0.55 \\
\hline Norway & 0.32 \\
\hline Spain: Synthetic unit countries & Coefficients \\
\hline Canada & 0.58 \\
\hline Hungary & 0.09 \\
\hline
\end{tabular}




$\begin{array}{ll}\text { Japan } & 0.04 \\ \text { Mexico } & 0.29\end{array}$

$\begin{array}{ll}\text { Portugal: Synthetic unit countries } & \text { Coefficients } \\ \text { Chile } & 0.55 \\ \text { Mexico } & 0.17 \\ \text { United Kingdom } & 0.28\end{array}$

Table A2: Covariates for real and synthetic units

\begin{tabular}{|c|c|c|}
\hline Finland & Treated (average 1975-1998) & Synthetic (average 1975-1998) \\
\hline Employment rate & 0.468 & 0.474 \\
\hline Real GDP (million 2011 USD) & 108212.1 & 148324.4 \\
\hline Population (millions) & 4.935 & 7.481 \\
\hline Labour share of GDP & 0.642 & 0.592 \\
\hline Capital stock (over GDP) & 4.905 & 3.608 \\
\hline $\begin{array}{l}\text { Share of government } \\
\text { consumption }\end{array}$ & 0.173 & 0.197 \\
\hline Trade openness & 0.713 & 0.706 \\
\hline $\begin{array}{l}\text { Population density (people per } \\
\text { sq. } \mathrm{km} \text { ) }\end{array}$ & 16.172 & 44.991 \\
\hline $\begin{array}{l}\text { Share of adults completed } \\
\text { secondary education }\end{array}$ & 18.577 & 20.317 \\
\hline $\begin{array}{l}\text { Share of adults completed } \\
\text { tertiary education }\end{array}$ & 8.086 & 8.123 \\
\hline Index of capital openness & 1.25 & -0.171 \\
\hline Market Gini Index & 41.2 & 41.485 \\
\hline France & Treated (average 1975-1998) & Synthetic (average 1975-1998) \\
\hline Employment rate & 0.404 & 0.355 \\
\hline Real GDP (million 2011 USD) & 1348352 & 629550.8 \\
\hline Population (millions) & 57.407 & 43.556 \\
\hline Labour share of GDP & 0.658 & 0.483 \\
\hline Capital stock (over GDP) & 4.628 & 3.068 \\
\hline $\begin{array}{l}\text { Share of government } \\
\text { consumption }\end{array}$ & 0.175 & 0.165 \\
\hline Trade openness & 0.447 & 0.317 \\
\hline $\begin{array}{l}\text { Population density (people per } \\
\text { sq. km) }\end{array}$ & 104.32 & 56.227 \\
\hline $\begin{array}{l}\text { Share of adults completed } \\
\text { secondary education }\end{array}$ & 17.09 & 17.003 \\
\hline
\end{tabular}


Share of adults completed
tertiary education
5.715
6.435
Index of capital openness
0.5
$-0.28$
Market Gini Index
47.708
47.766

Germany
Rmployment rate
Peal GDP (million 2011 USD)
Labor share of GDP
Capital stock (over GDP)
Share of government
consumption

Treated (average 1975-1998) Synthetic (average 1975-1998)

0.484

0.461

1865113

768551.4

79.158

30.265

0.67

0.646

4.448

4.258

consumption

0.152

0.172

Trade openness

0.574

0.575

Population density (people per

sq. km)

227.107

56.566

Share of adults completed

secondary education

18.646

22.907

Share of adults completed

tertiary education

6.989

11.518

Index of capital openness

2

1.753

Market Gini Index

43.275

43.168

$\begin{array}{lll}\text { Greece } & \text { Treated (average 1975-1998) } & \text { Synthetic (average 1975-1998) } \\ \text { Employment rate } & 0.39 & 0.346 \\ \text { Real GDP (million 2011 USD) } & 170406.5 & 366135 \\ \text { Population (millions) } & 10.185 & 30.193 \\ \text { Labor share of GDP } & 0.49 & 0.489 \\ \text { Capital stock (over GDP) } & 5.654 & 2.878 \\ \text { Share of government } & & \\ \text { consumption } & 0.16 & 0.169 \\ \text { Trade openness } & 0.29 & 0.322 \\ \text { Population density (people per } & & \\ \text { sq. km) } & 78.248 & 21.472 \\ \text { Share of adults completed } & & \\ \text { secondary education } & 21.58 & 21.631 \\ \text { Share of adults completed } & & \\ \text { tertiary education } & 9.677 & 7.217 \\ \text { Index of capital openness } & -0.444 & -0.426 \\ \text { Market Gini Index } & 49.007 & 48.832\end{array}$




\begin{tabular}{|c|c|c|}
\hline Ireland & Treated (average 1975-1998) & Synthetic (average 1975-1998) \\
\hline Employment rate & 0.351 & 0.352 \\
\hline Real GDP (million 2011 USD) & 59618.57 & 285721 \\
\hline Population (millions) & 3.523 & 16.597 \\
\hline Labor share of GDP & 0.554 & 0.543 \\
\hline Capital stock (over GDP) & 4.247 & 2.936 \\
\hline $\begin{array}{l}\text { Share of government } \\
\text { consumption }\end{array}$ & 0.186 & 0.196 \\
\hline Trade openness & 1.152 & 0.344 \\
\hline $\begin{array}{l}\text { Population density (people pe } \\
\text { sq. } \mathrm{km} \text { ) }\end{array}$ & 50.726 & 14.023 \\
\hline $\begin{array}{l}\text { Share of adults completed } \\
\text { secondary education }\end{array}$ & 21.301 & 23.851 \\
\hline $\begin{array}{l}\text { Share of adults completed } \\
\text { tertiary education }\end{array}$ & 8.684 & 7.99 \\
\hline Index of capital openness & 0.375 & -0.432 \\
\hline Market Gini Index & 48.758 & 48.753 \\
\hline Italy & Treated (average 1975-1998) & Synthetic (average 1975-1998) \\
\hline Employment rate & 0.385 & 0.373 \\
\hline Real GDP (million 2011 USD) & 1281408 & 554263 \\
\hline Population (millions) & 56.78 & 46.563 \\
\hline Labor share of GDP & 0.573 & 0.475 \\
\hline Capital stock (over GDP) & 4.888 & 3.19 \\
\hline $\begin{array}{l}\text { Share of government } \\
\text { consumption }\end{array}$ & 0.142 & 0.137 \\
\hline Trade openness & 0.372 & 0.408 \\
\hline $\begin{array}{l}\text { Population density (people pe } \\
\text { sq. km) }\end{array}$ & 192.211 & 30.322 \\
\hline $\begin{array}{l}\text { Share of adults completed } \\
\text { secondary education }\end{array}$ & 15.901 & 13.783 \\
\hline $\begin{array}{l}\text { Share of adults completed } \\
\text { tertiary education }\end{array}$ & 3.586 & 6.147 \\
\hline Index of capital openness & -0.042 & 0.13 \\
\hline Market Gini Index & 45.538 & 45.517 \\
\hline Italy & Treated (average 1975-1998) & Synthetic (average 1975-1998) \\
\hline Employment rate & 0.385 & 0.373 \\
\hline Real GDP (million 2011 USD) & 1281408 & 554263 \\
\hline Population (millions) & 56.78 & 46.563 \\
\hline
\end{tabular}




\begin{tabular}{|c|c|c|}
\hline Labor share of GDP & 0.573 & 0.475 \\
\hline Capital stock (over GDP) & 4.888 & 3.19 \\
\hline $\begin{array}{l}\text { Share of government } \\
\text { consumption }\end{array}$ & 0.142 & 0.137 \\
\hline Trade openness & 0.372 & 0.408 \\
\hline $\begin{array}{l}\text { Population density (people per } \\
\text { sq. km) }\end{array}$ & 192.211 & 30.322 \\
\hline $\begin{array}{l}\text { Share of adults completed } \\
\text { secondary education }\end{array}$ & 15.901 & 13.783 \\
\hline $\begin{array}{l}\text { Share of adults completed } \\
\text { tertiary education }\end{array}$ & 3.586 & 6.147 \\
\hline Index of capital openness & -0.042 & 0.13 \\
\hline Market Gini Index & 45.538 & 45.517 \\
\hline Spain & Treated (average 1975-1998) & Synthetic (average 1975-1998) \\
\hline Employment rate & 0.345 & 0.418 \\
\hline Real GDP (million 2011 USD) & 625320.2 & 825707.3 \\
\hline Population (millions) & 38.678 & 44.436 \\
\hline Labor share of GDP & 0.64 & 0.608 \\
\hline Capital stock (over GDP) & 4.538 & 3.65 \\
\hline $\begin{array}{l}\text { Share of government } \\
\text { consumption }\end{array}$ & 0.135 & 0.145 \\
\hline Trade openness & 0.307 & 0.41 \\
\hline $\begin{array}{l}\text { Population density (people per } \\
\text { sq. km) }\end{array}$ & 76.86 & 36.916 \\
\hline $\begin{array}{l}\text { Share of adults completed } \\
\text { secondary education }\end{array}$ & 7.542 & 19.282 \\
\hline $\begin{array}{l}\text { Share of adults completed } \\
\text { tertiary education }\end{array}$ & 5.792 & 10.005 \\
\hline Index of capital openness & 0.333 & 1.181 \\
\hline Market Gini Index & 43.554 & 43.586 \\
\hline
\end{tabular}


Figure A1: Placebo plot for Finland

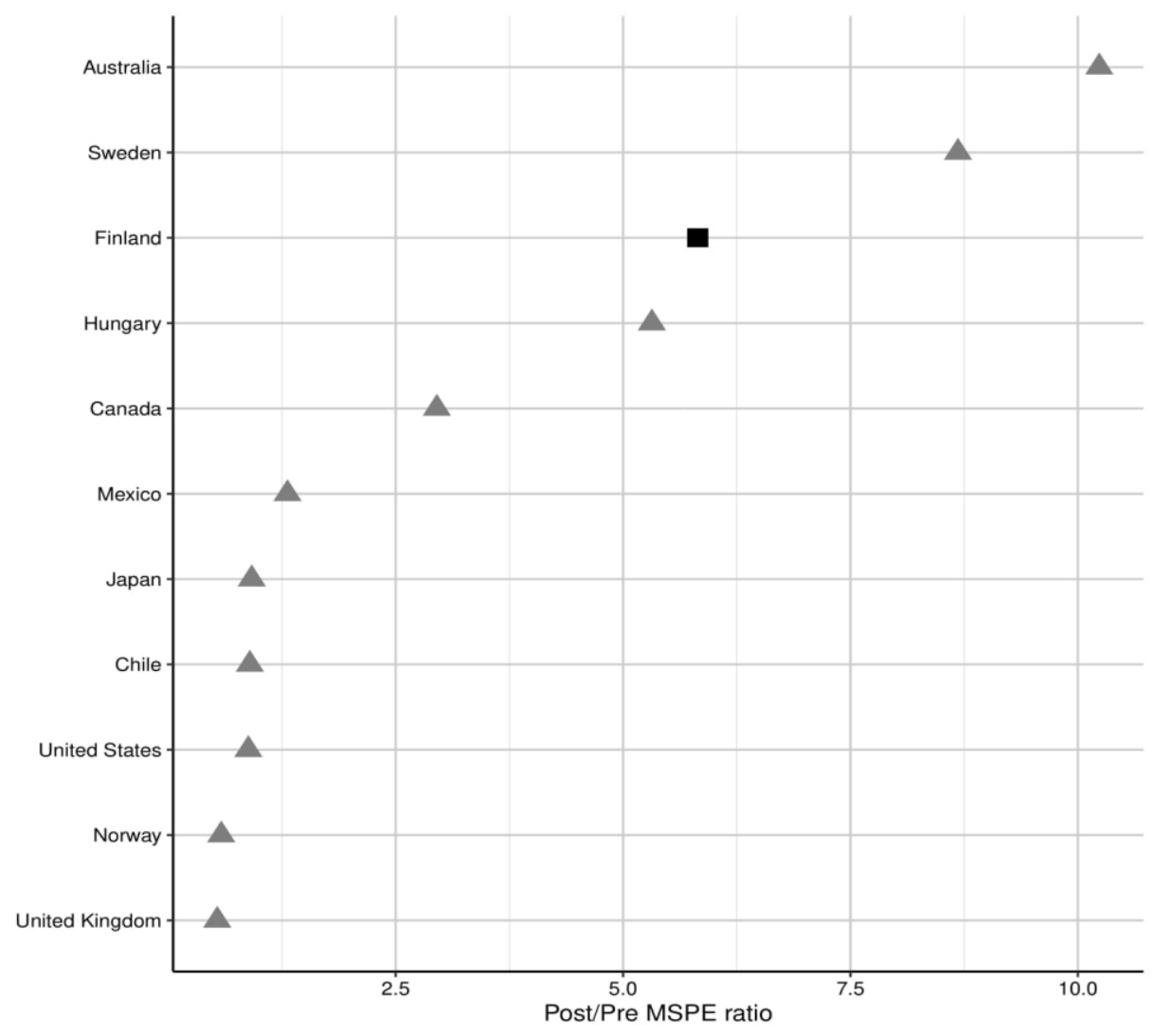

Figure A2: Placebo plot for France

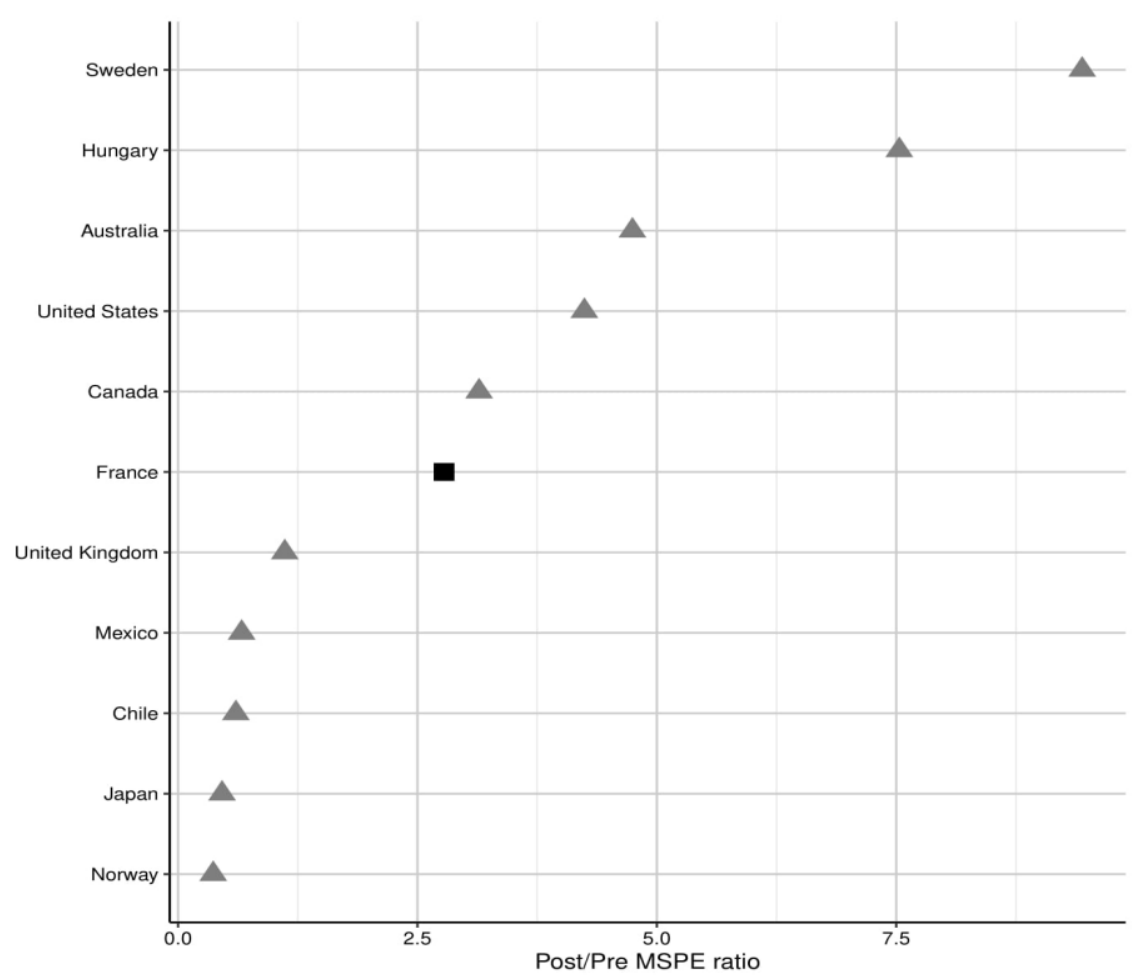


Figure A3: Placebo plot for Germany

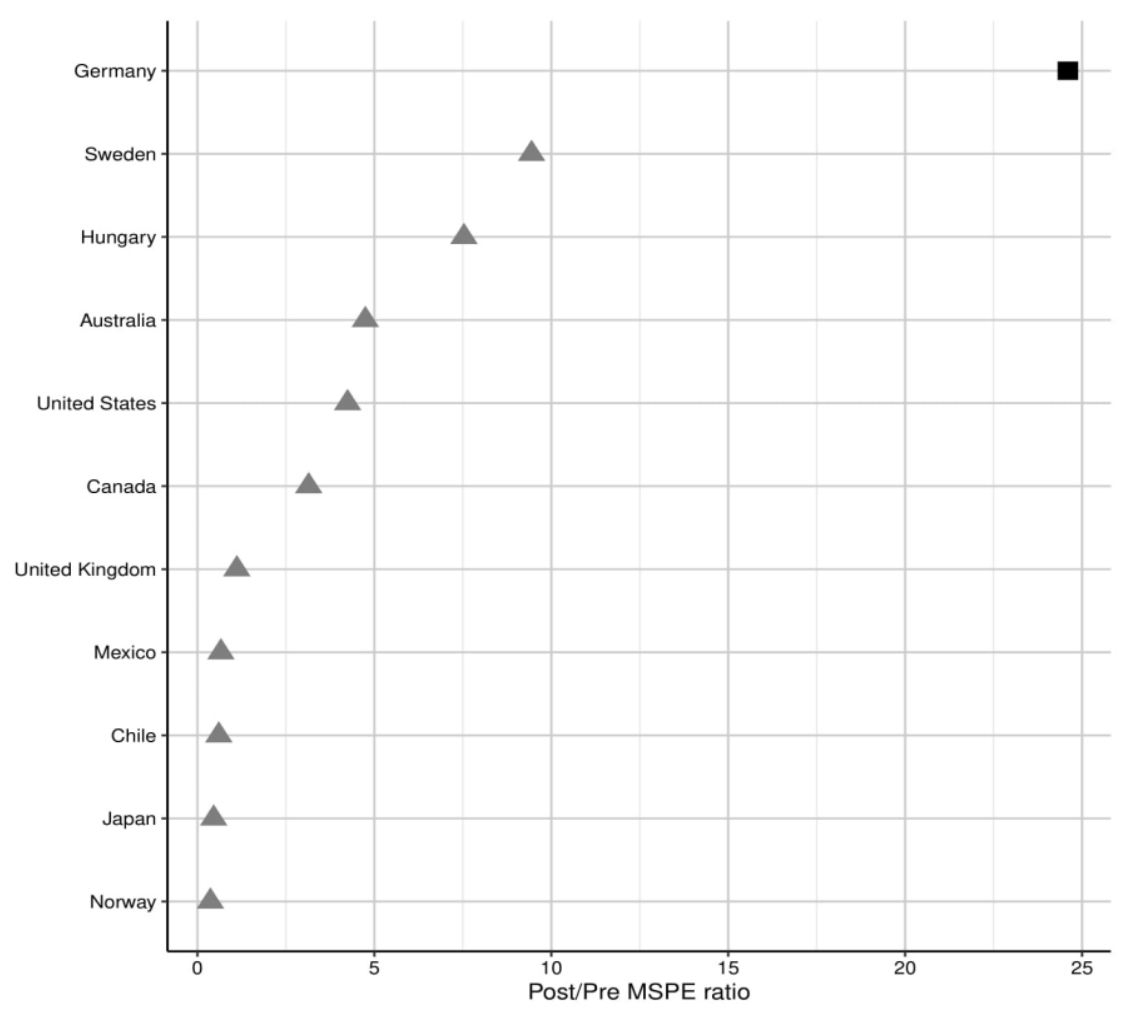


Figure A4: Placebo plot for Greece

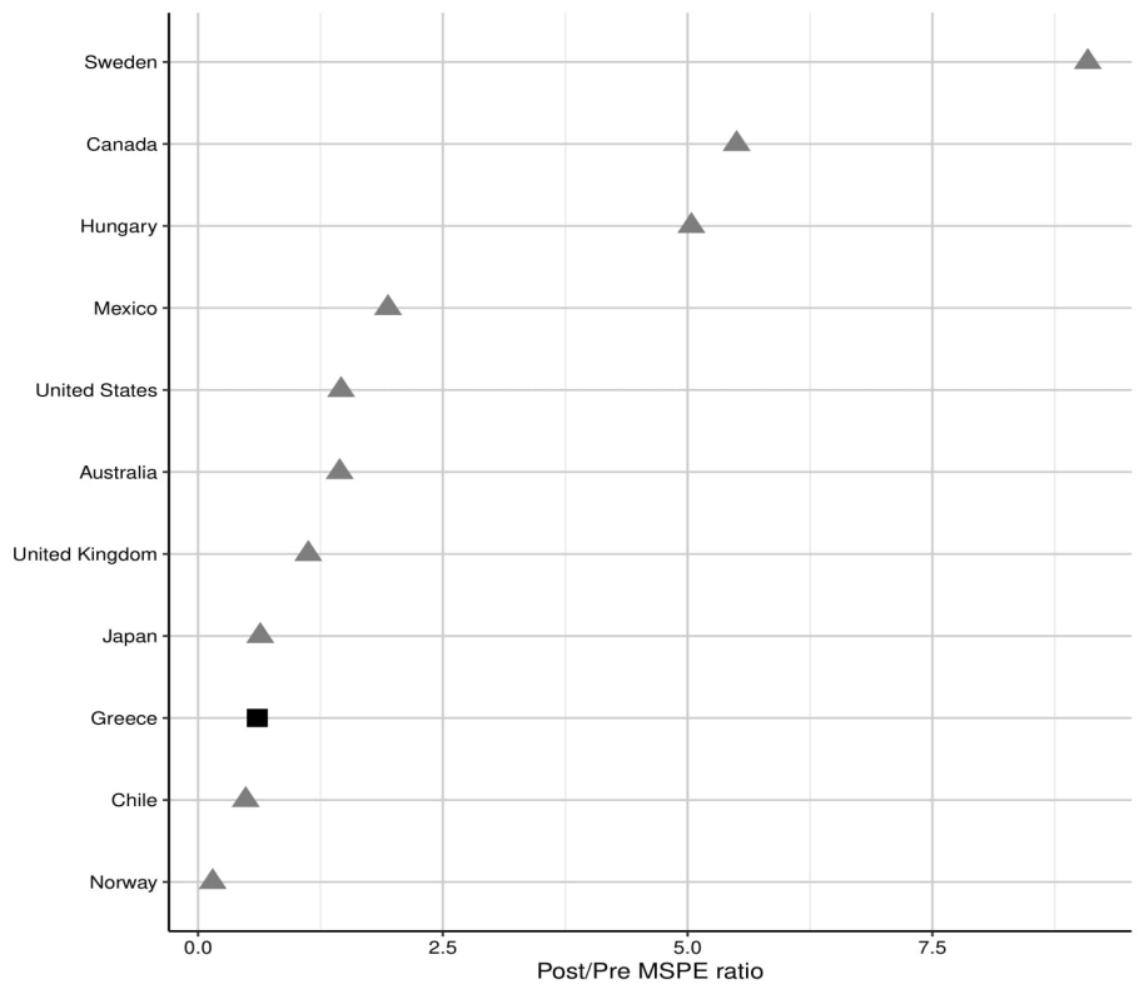

Figure A5: Placebo plot for Ireland

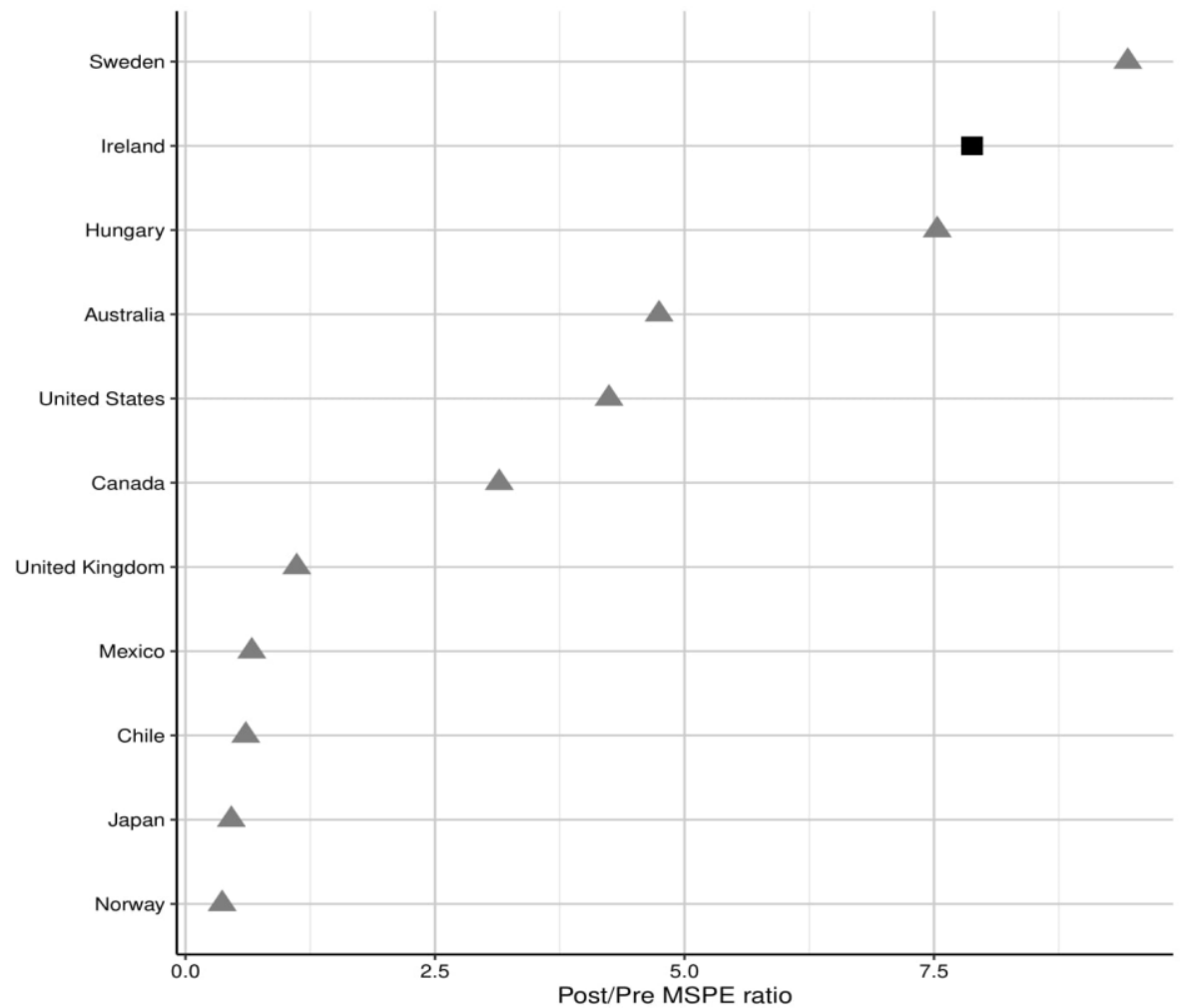


Figure A6: Placebo plot for Italy

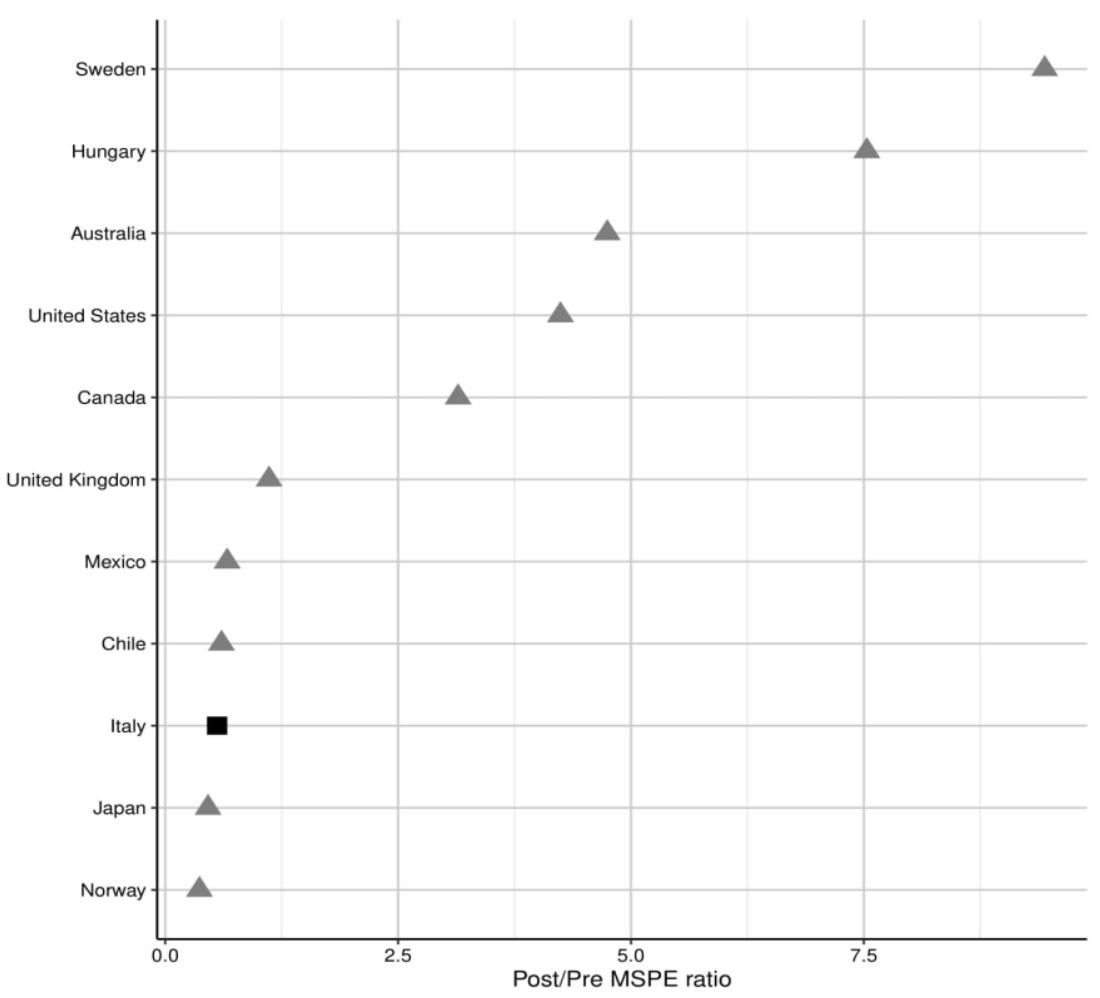

Figure A7: Placebo plot for Portugal

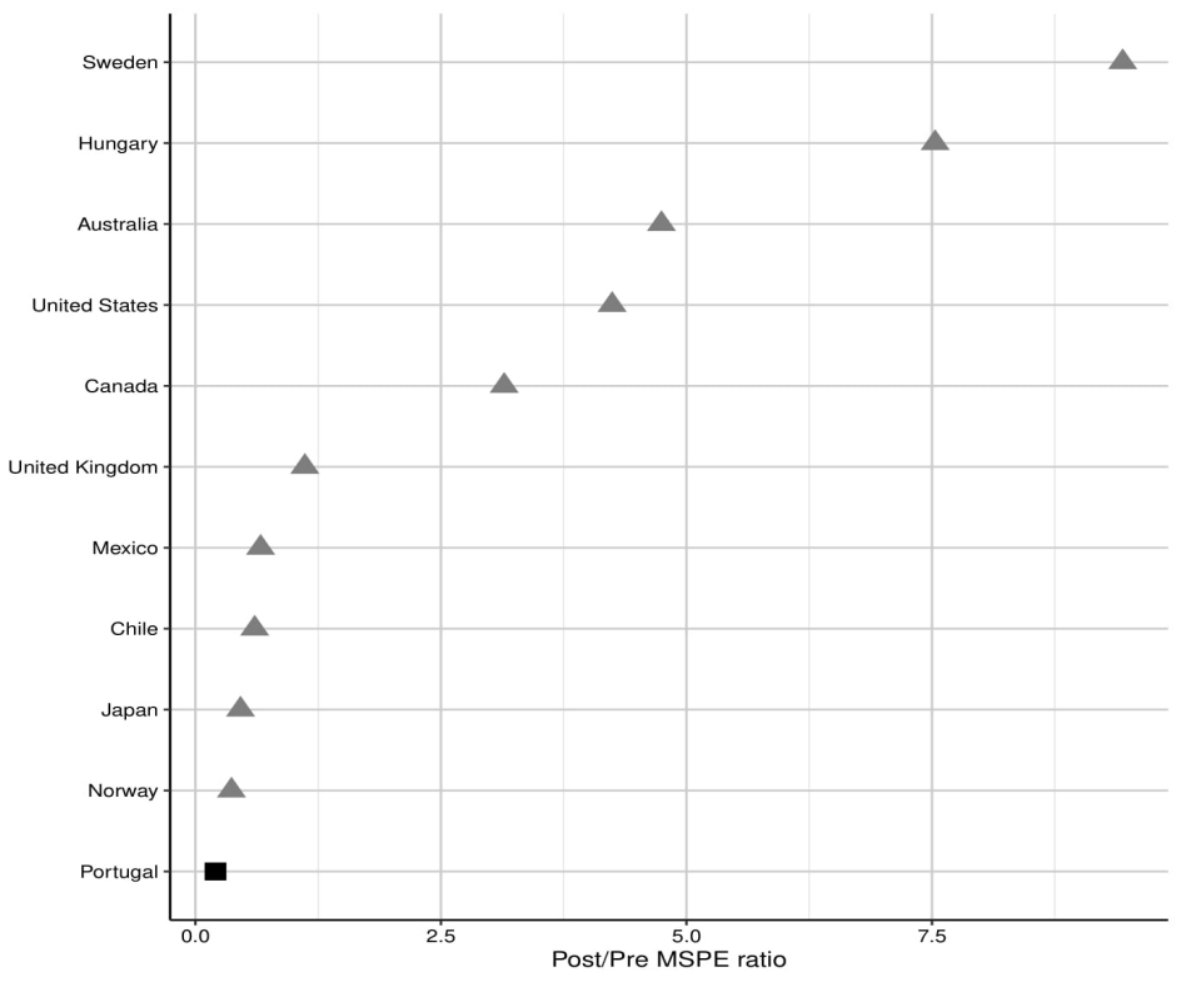

33 
Figure A8: Placebo plot for Spain

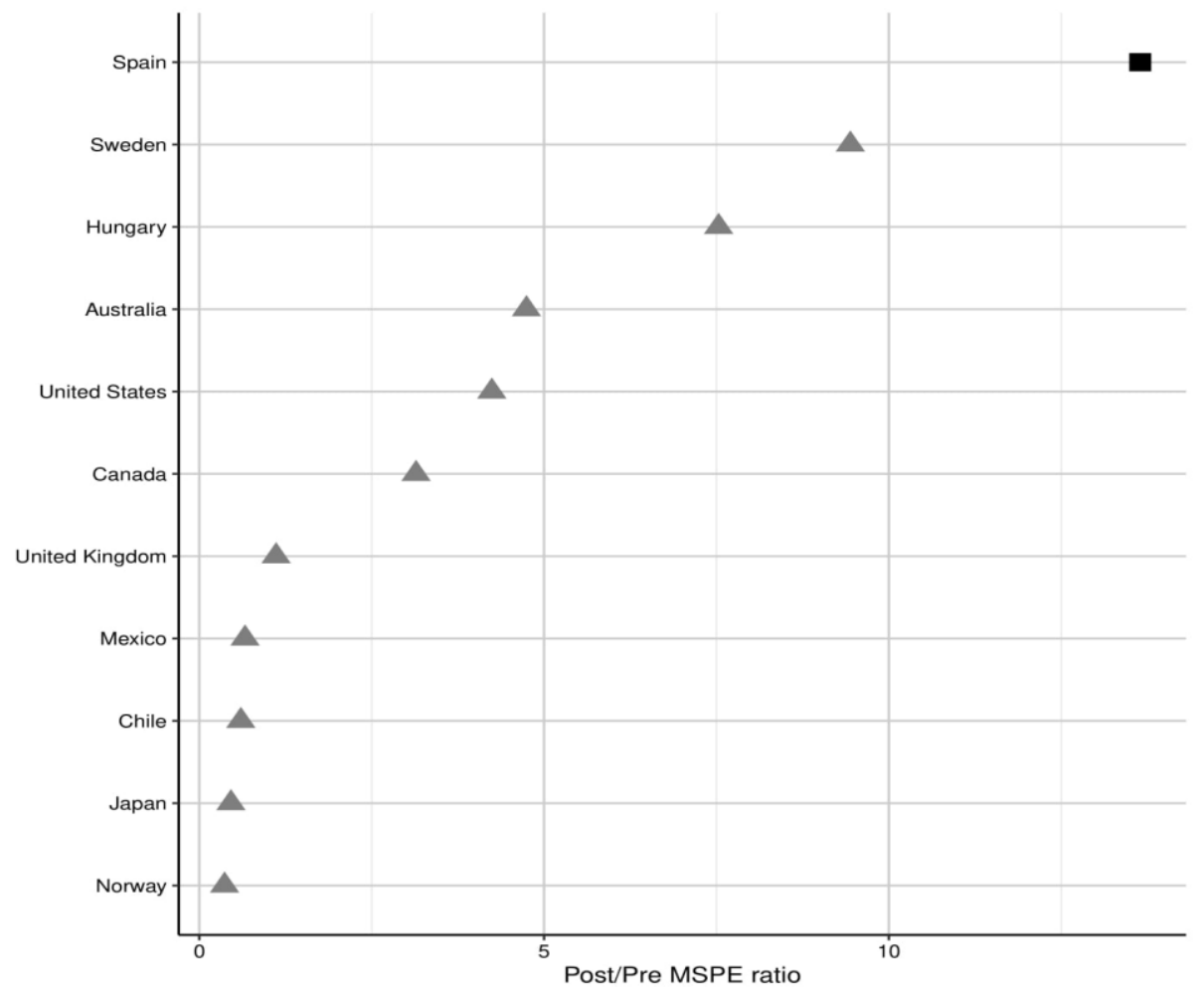


Figure A9: Path and Gap plots for OECD donor pool only
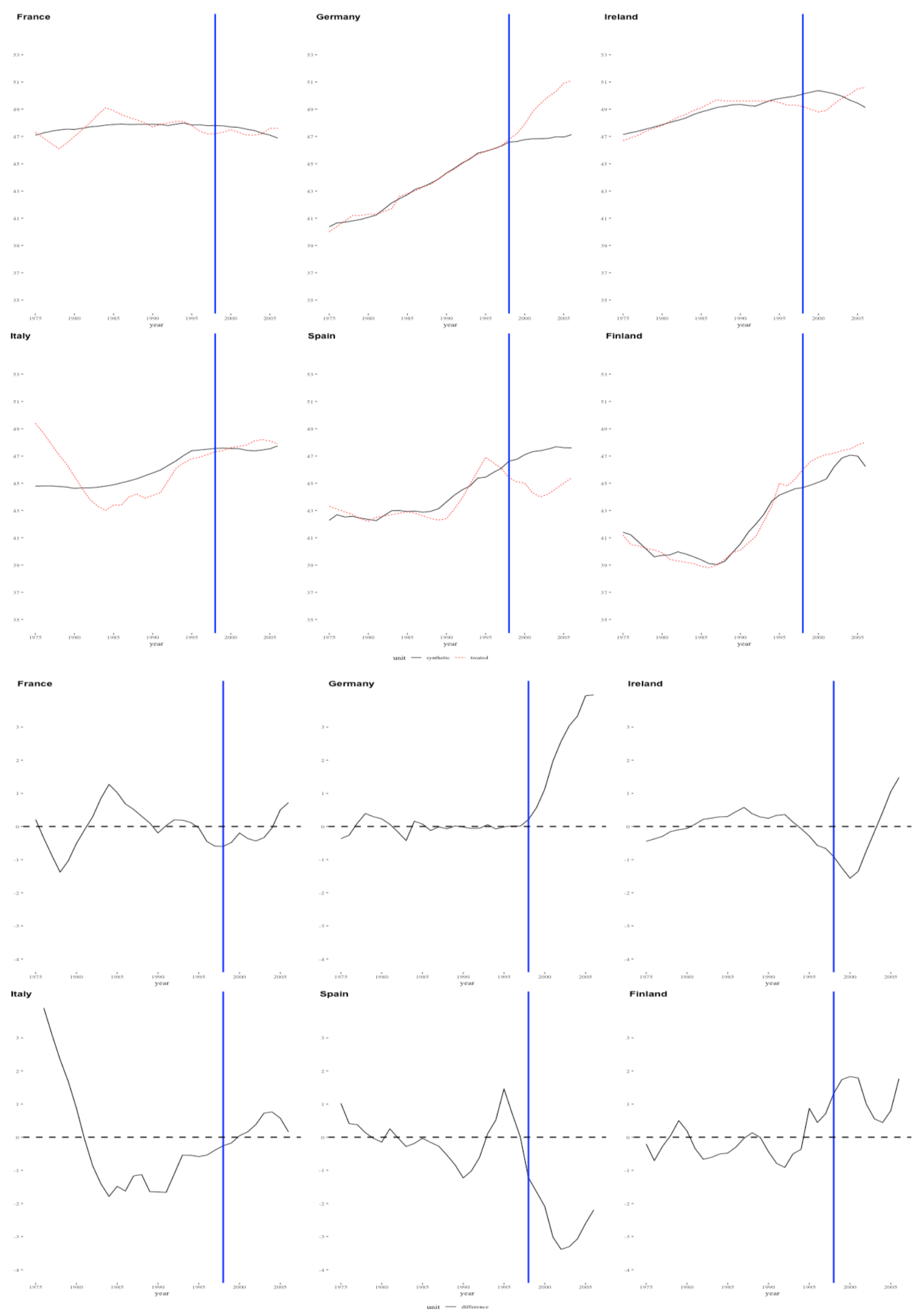

35 